\title{
Demographics and the Irony of Existential Profiling in Yorùbá Thought: Policy Considerations for Nigeria
}

\author{
Wale Olajide \\ Department of Philosophy \\ Ekiti State University \\ ashaolu54@yahoo.co.uk
}

\begin{abstract}
This essay interrogates what can be described as Yorùbá population philosophy, within the context of Yorùbá existential thought, and the effects it has on Nigeria's population explosion. The essay explores the seemingly contradictory proverbs that both vindicate and vilify the act of giving birth to many children. The essay further connects this traditional Yorùbá wisdom to contemporary procreative practices of Yorùbá Christians and Muslims, and their interpretations of scriptural injunction to be fruitful and multiply. I then argue that if Nigeria's lackluster policy on population is taken into consideration, the implications of the Yorùbá, as well as other ethnic groups', population philosophy will not only aggravate the Nigerian postcolonial predicament, but will eventually explode the population time bomb already ticking in Nigeria. The essay recommends that given the existential complexities attached to giving birth to a child, together with the demographic exigencies on Nigeria's national predicament, marriage ought to be strictly regulated and limited to those with the capacity for sustainability.
\end{abstract}

Keywords: Procreation, Population growth, Existence, Overpopulation, Omọ l'aṣo 


\section{Preamble}

If a state of affairs is adjudged to have been mistaken, and is subsequently recognized to be so, then there is at least some hope of slowing it down and even reversing or stopping it altogether. This projected optimism would of course only be applicable in a situation where the mistake is identified and accepted as being truly a mistake and the culprit most willing to reassess the situation. It would in that case be assumed that the mistake might have been a case of either an omission or one of commission but never premeditated and therefore not deliberate. The prospect of culpability may therefore be evident on the part of the agent but pardon would at least be swift in coming.

Not so however with the case that this essay seeks briefly to discuss, namely, existential procreation profiling in Yorùbá thought and its probable impact, by way of contribution, on Nigeria's demographic narrative with a caveat that if the drift is not reversed and/or possibly halted, the postcolonial realities in Nigeria are made all the more unbearable, and the government becomes all the more irresponsible. I have used the term "contribution" to candidly underscore the fact that rather than being seen as attempting to isolate and stereotype the Yorùbá, the excessive procreation malady being discussed is also a definitive prominent feature in both the Igbo and the Hausa thought systems, the other two major regional nationalities in Nigeria. In the former, the term proliferation will definitely serve as a very appropriate synonym for procreation where a family unit of one man and one woman has, for instance,, eight children and still counting. With the latter, particularly because of the added indulgence of the Islamic religion which permits polygamy, the resulting figures of children are far larger with attending social features of vagrancy, fugitiveness, homelessness, illiteracy, and, of course, different cases of child abuse and street begging, at least in its Nigerian incarnation.

I start with the thesis, which, by its internal logic, recognizes procreation solely as a human act that is guided by human rationality and deliberate choice. Consequently both the choice and the responsibility attached rest squarely on the shoulders of the agents. ${ }^{1}$ So too would be other consequences, both proximate and remote, that follow the decision to procreate. I shall then $\mathrm{x}$-ray the position of the Yorùbá on procreation showing why and how it is flawed generically and also in its logic and how the continued practice of reckless procreation by its people fearfully portends a demographic disaster for Nigeria. Added of course is the social menace of poverty, illiteracy, vagrancy,

1 The thesis was exhaustively treated in my inaugural lecture (Olajide 2017), in which I argued for restraints on procreation since coming into existence does no good for the baby. He or she never requested to be born. Besides, coming into existence is always harmful. 
and insufficient poor infrastructural support and youth restiveness. I shall end with few suggestions on policies that could perhaps, if considered and adopted, forestall the real and present danger of a gross mismatch of thought, practice and resources.

\section{In the Beginning}

The evolutionary path has brought mankind thus far. Specifically on the question of sex, Homo sapiens have turned out male and female children without any serious outlandish metaphysical justification. X and Y constitute the sex chromosomes. The Y, particularly the gene SRY (i.e. the Sex determining Region of the $\mathrm{Y}$ ), is responsible for the characteristics that transform the human body into the male. Male or female, each carries chromosomes that exist in pairs: twenty-three from the mother, including the $\mathrm{X}$ chromosomes, and twenty-three from the father, including either an $\mathrm{X}$ chromosomes for daughters and $\mathrm{Y}$ chromosomes for sons. It follows that females have two $\mathrm{X}$ chromosomes while males have just one $\mathrm{X}$ and one $\mathrm{Y}$ chromosomes. Dick Swaab, the renowned neuroscience researcher, is very explicit:

The boy's Y chromosome starts the process that causes the male hormone testosterone to be produced. The presence or absence of testosterone makes a child develop male or female sex organs between the sixth and twelfth week of pregnancy. The brain differentiates along male or female lines in the second half of pregnancy, due to a male boy producing a peak of testosterone or a female baby not doing so. It's in that period that the feeling of being a man or woman-our gender identity-is fixed in our brain for the rest of our lives $(2014,56)$.

It is interesting to note that of the near twenty-three thousand genes that the human body carries, only a mere one-thousandth of these, just twenty-five genes, lie on the $\mathrm{Y}$, sealing the fate of male species that has peopled the entire world. However, whatever significance is attached to the statistical variance quickly vanishes against the soaring influence of turning out male, socially, politically, economically, and culturally. As Graig Venten interestingly notes in his autobiography,

For a people cursed with a Y chromosome, life is hard from the very start and only gets tougher. Look at the oldest residents of this planet and you will see they usually lack Y chromosomes. From fertilization to death, those who bear these chromosomes are in relative decline compared with those blessed with two X's. The Y confers many peculiarities, from a greater 
risk of committing suicide, developing cancer, and becoming rich, to having less hair on the top of the head $(2017,9)$.

The Yorùbá people sum it up most appropriately with the declaration: "kò rọùn láti jẹ ọmọùnrin ("it is not easy to be male"). Both the male and the female species are however fully engaged in the business of procreation.

Humans crave sex in order to reproduce because, as I shall soon highlight, the ultimate cause of sex is reproduction. Yet as Steven Pinker rightly submits, and as it is so concretely affirmed by the evolutionary history of birth control, humans sometimes may and do in fact overlook this ultimate cause of sex for the proximate cause of sex, which is pleasure (Pinker 2002, 51-58). ${ }^{2}$ Beyond pleasure however, and in whatever form or manner even in the face of its stark fleetingness, the ultimate reason for sex is procreation. This is an evolutionary fact that forms a universal base for all species and in particular the Homo sapiens. I emphasize this distinction because of the inference that I shall soon make to the effect that procreation ought to be, and, specifically so in the case of Homo sapiens, a deliberate conscious act and decision with far reaching consequences that demand huge responsibility of the major agents involved in the act. Birds and bees of course procreate, as do monkeys, elephants, and chimpanzees. Yet, I will not be willing too readily to inhibit these species with the qualification and demands set for Homo sapiens above. My argument is simple: "the act of making babies must always be queried. This is simply because procreation goes beyond merely having the enabling biologi$\mathrm{cal}$ instruments. It also certainly goes beyond cultural dictates and the social institution of marriage" (Olajide 2017, 35). Once it is granted that procreation is a deliberate choice action it means that it is executed with the rational processes of thinking and reasoning, of deciding and choosing. No aspect of this-as long as humans remain rational-should therefore be blind, jaundiced, or arbitrary. There should also be no room for contingencies, since, beyond the fears of premature births or of babies that might be born with congenital diseases, brain damage, or grave physical deformities, the birth of babies is regarded as a complete and finished act, which in some cultures is always greeted with loud celebrations.

Darwinian evolution submits that procreation is not merely a result of the male and female wanting and choosing to replicate themselves, but on the contrary, beyond the wish itself is the question of survival of their species. Homo sapiens must keep itself in perpetuity and to do this multiplication

2 The recent rise in the use of aphrodisiacs by men and women underscores the proximate emphasis of sex for pleasure. The same point is made relevant by the obvious anxiety regarding loss of libido by men beyond the age of fifty and their readiness to try any solution offered to them, no matter how crude. 
must go on. That humans today are at the apex of the evolutionary pyramid while only mere bones of dinosaurs are left locked up in museums emphasizes the point. Procreation therefore is de facto part and parcel of the evolutionary narrative of Homo sapiens in their struggle for the survival of the fittest. On the sole reason of self-preservation and perpetuity of the human species therefore, procreation remains justified. But only thus far can this be justified, outside of the indulgence of unbridled procreation. This is because procreation in itself does not occur in a vacuum.

The human world in its microcosm embraces human societies, which forms the immediate environment into which every Homo sapiens is born. The power of the environment is actively huge and to a large extent functioning in full collaboration with the performance of the brain, determining who and what each man or woman eventually turns out to be in all and every ramification of human existence. The environment undoubtedly has resources that support the prospects of human flourishing and its survival. It is for this singular truism that the nature-nurture discourse has remained central to the question of holistic human development.

Also, except in rare cases of famine, there is no discrimination regarding access to any of the natural environmental resources particularly the consumables, such as water and food. Both may be abundantly available but they could dwindle and simply vanish in the case of drought and subsequent poor harvest, as evident in some countries north of the Sahara. Food baskets must constantly be replenished through a farming system that beats irreverent and unpredictable seasons. Yet against all odds, as witnessed in countries of the so-called third world that survive on foreign food aid, these resources often fail with a major contributor being excessive and reckless birth proliferation. In fact, with some deep religious sense one could do the math that procreation, when added to the scarcity of sustainable resources and population, yield existential Holy Trinity. Where procreation becomes unthinking and reckless to the extent that it takes little or no notice of population growth and the availability of adequate sustainable resources, it is literally doomsday, a running hour glass of death and ultimate extinction. This urgently places the responsibility on humans to rethink the idea of procreation as a survival imperative. Better still, if the human species wishes to justify the claim of rationality, then right thinking demands that common sense takes precedence with the careful watching and matching of available and projected sustainable resources with the human survival project. The eyes of every nation and culture must therefore at all times be fixed on the ball.

There is more. If the decision to reproduce and replicate is ultimately and essentially a rational choice, then it follows that the choice belongs solely to the agents involved, namely, the man and the woman, and to no one else. Not 
to any third party, culture, or tradition, and most certainly not to any metaphysical being by whatever name such a being is called and whatever its attributes are. It is essentially the choice and decision of the agents to bring yet another human being into the world. It follows therefore that in all and every case of birth, no one existing on earth ever asked to be born. ${ }^{3}$ In every birth and on all occasions:

there was no dialogue... [m]aking babies remains at its core a selfish act of two consenting or non-consenting adults for which no thanks should be offered. On the contrary, the party that made it all happen owes the victim an apology because of their act. When stripped to its bare bones, being born is a huge disservice apart from also being cruel and reckless (Olajide, ibid.).

It is instructive to emphasize this particular point in response to some cultures that continue to insist that being born is a gift. For whom is it a gift? Perhaps it may be to the agents who might have been wishing for a baby, having had a barren spell in marriage, but certainly not for the baby.

If the reference is to the gift of being born, which in this case refers to the baby, then the submission would certainly be mistaken and deliberately mischievous. I agree completely with the submission of David Benatar that coming into existence is always a form of doing harm. This is partly because whatever fate awaits the newborn baby, be it pleasant or cruel, much of it would be influenced and determined by the environment into which he or she is born. Imagine the children born into conflict, raised in conflict, and who, eventually, with no other possible living experience, die in it. Some still are born of parents fleeing from war-torn regions only to live and die in refugee camps, severely ravaged by acute malnutrition and severe ill-health. Even in countries where some semblance of subsistence seems to exist, poor governance, deplorable infrastructure, abject underdevelopment, and derelict leadership postures often conspire and make existential flourishing simply hopeless. According to Benatar, at the risk perhaps of stating the obvious, "all lives contain some bad. [But] coming into existence with such a life is always a harm.... [O]ften the suffering is excruciating [when] we infrequently contemplate the harms that await any new born child - pain, disappointment, anxiety, grief and death" $(2006,29)$. I need not stress here the horrors that attend some forms of death for no fault of the victims who, if we must be reminded, were never consulted whether they would fancy visiting the earth nor was it

3 This is true of all cases, except the story of the biblical Jesus Christ is believed. We are told that he, in a pre-existent life, volunteered to come into the world and redeem the human race of its sin. 
ever stated anywhere that they shared or voiced any interest whatsoever. And let not the argument be raised that being born in North America or Europe is better than, say, being born in the Third World. All humans are subjected to the same existential grief of existence.

Inferring from the above, it should now be readily obvious that one can never be brought into existence for his or her own sake or for any purported good for that matter. To claim otherwise, and then to seek to enforce such a claim with the sledgehammer of tradition and religion is sheer fraud, cruelty, and essentially a deception. Being born essentially does no service-and is of no benefit-to the individual born. If anything, the latter is a condemned pathetic victim. By extension, coming into existence is essentially bad luck. What is hugely disconcerting, when the tragic horrors of coming into existence are put in perspective and the impact of excessive procreation or overpopulation on human flourishing is revealed, is the fact that the situation which could have been avoided or at least minimized, was made only possible by the deliberate act of two consenting rational adults. ${ }^{4}$ Where it is done judiciously in the name of species survival, some justification may be found. But when it is done however with so much reckless abandon, and with little or no regard for the narrative of population status and the resources available to thrive on, only strong condemnation in superlative terms will suffice.

\section{The Yorùbá Culture and the Dynamics of Procreation}

The Yorùbá, by culture and religion, love babies. They relish it and show utter disdain for barrenness or for infertility in marriages and all other forms of celibacy. This is true of not only the Yorùbá people but indeed of most if not all communities in Africa. Genealogy is a prized consideration among the Yorùbá, since for them the family is everything. It defines strictly their belongingness-the fact that they are not vagabonds, but a people with roots. It is the aspiration of the Yorùba to be able to trace the identity of a person to his or her community. This is because, "It is the community that would protect the child, feed it, nurture and educate it both in formal and informal ways and incorporate it into the wider community" (Olajide 2017b, 185). The love of babies thus firmly established, is it then the case that acts of procreation among the Yorùbá traditional society are always measured, deliberate, and adjudged necessary in relation to availability of sustainable resources and in

4 It is not uncommon to hear couples say that they never planned nor wanted the pregnancy that resulted in the birth of their baby. It was a mistake they usually confessed. But rather than deal with the mistake there and then through perhaps the choice of an abortion, just one more additional digit to human population is considered discountable they reckon especially in cultures where God always provides and guarantees everything. 
full cognizance of population realities, particularly with regards to individual families head count as it impacts the general society? I do not think so.

This answer requires a serious caveat. Let it be stated categorically that the Yorùbá cultural lore is a rich one that projects a pragmatic observation and consideration of issues. The demographic matter of procreation is one fundamental one on which the Yorùbá traditional culture has weighed both sides of the coin with solemn consideration. On the one hand, there is a cultural permissiveness that derives from the belief that it is Olódùmarè who is the source of the joy of childbirth. In fact, when the Yorùbá say ọmo l'aṣọ ("children are garments"), there is at play a critical principle of social relations that equates abundance of people with true wealth. Thus, Owomoyela remarks that

the reduction of the concept "wealth" to an abundance of people around one, as in Ẹni tí ò lówó a léèyàn... ("Whoever lacks money should have people..."), or the equation of wealth (in clothing) with abundance of children, as in Omọ laṣo ("Children are garments"), lends credence to the claim that the maintenance of good relations is of crucial importance in Yoruba social life $(2005,34)$.

This social relations principle goes a long way to reaffirm the belief in procreation as a virile sign of wealth and favor from the gods. Several proverbs confirm this:

\section{A ki i ko ọmo bii ká sọ ọ ní Ėwolódé?}

"One does not so resent having a child that one names it What-is-this-thathas happened?"

(Childbirth is always a happy event) (ibid, 92)

Bí a bá ní ogún ẹrú, tí a ní ìợ fà ogbọn; ọmo lèrè ẹni

"If one owns twenty slaves and thirty pawns, children are still one's profit" (ibid, 277)

\section{A kì i délé ayò ká má bá ọmo}

"One never arrives at the home of the ayò game without finding children" (ibid, 281)

İyàwó dùn-ún gbé; ọmọ dùn-ún kó jáde

"Marriage is a pleasurable activity, and so is christening a child" (ibid, 282)

Kí ni à bá fowó rà tó lè kọjá ọmọ? 
"What can one use one's money to buy that would be more precious than children?" (ibid.)

Thus, if babies are ultimately gifts from Olódùmarè and are the signs of providential favor, as the Yorùbá belief goes, then one is as wealthy as the number of children one has. Indeed, by saying olọmọola ("the person that is blessed with children has prospered"), the Yorùbá immediately signal the premium that is put on children. Within this mindset, more babies are born without any serious critical thought of the how of their flourishing and survival. Even where so suddenly some women perhaps because of the reasons of age or ill-health stopped bearing children, families encourage their husbands with zest to take on younger wives to carry on the business of procreation. This attitude stems from yet another strong belief of the Yorùbá: Eni ti kò bímọ wáyé lásán ("a person who is barren lives an empty life"). J. S. Mbiti notes the significance of procreation and fertility in a larger African cultural context: "Unhappy is the woman who fails to bare children for, whatever other qualities she might possess, her failure to bear children is worse than committing genocide; she has become the dead end of human life; not only for the genealogical line but also for herself" $(1969,11)$.

From the first indication that a new baby is on the way, special treatment is accorded the expectant mother. Pregnancy is a sign that prayers and sacrifices offered during the marriage ceremonies have indeed found favor with God. And this is reflected in some of the names given to babies. Among the indigenous Yorùbá for example, children that are received as gifts from the gods are easy to recognize. Those from Òsun, the river goddess, carry names prefixed by the name of the goddess herself: Ộṣunrẹmílẹkún (Ộsún has put a stop to my weeping), Ọsúngbèmí (Ộṣún is on my side), Ợṣúnkàmíyẹ (Ộsún has found me worthy), Ọsúnlànà (Ọ’șún has opened the way). Those from the goddess Oya include: Oyáwálé (Ọya has come home), and Oyalẹwàmi (Oya is my beauty). From Șàngó, the god of thunder, we have: Șàngóbùnmi (Șàngó has given me this), and Șàngógbèmí (Șàngó is my benefit). From Ėṣù: Èșúgbàyí (Ėșù has taken the honor), and Ėsúmòmí (Èșù has recognized me). From Ògún, the god of iron, there are: Ògúnyẹmí (Ògún has fittingly blessed me), Ògúndọlà (Ògún has brought riches), Ògúnkọyà (Ògún has refused dishonor). From the contemporary Yorùbá community tainted by Christian theology, it is common to have the following: Olúwașèyífúnmi (God did this for me), Olúwașeun (God I thank you), Olúwabùkúnmi (God has blessed me), Olúwapamílérin (God has made me laugh), Olúwajọba (God is enthroned King), Olúwadárasími (God has been good to me), and Olúwadámilóhùn 
(God has answered me), to mention a few. ${ }^{5}$ Of particular significance are twins (ibeji), whose arrival the Yorùbá associate with riches and prosperity for the lucky parents. Ironically it is very common to find mothers engaged in street begging, seemingly oblivious of the disconnection between what they profess and the reality in which they now must live in order for both the mother and her babies to survive.

Whatever fawning attention the mother of a baby enjoyed before the arrival of the baby, and immediately after the baby's birth, soon evaporates a few weeks after the naming ceremony. Everything quickly returns to normal as the father and the mother of the child return to the hard realities of their existence. And it is at this juncture that we arrive at the second but pragmatic cultural observation of the traditional Yorùbá culture. Here we encounter counteracting proverbs that seem to circumscribe any proclivity for recklessness in procreation:

"Mo bí, mo bí" kì íṣe ọmọ rere

"'I have just had a baby; I have just had a baby!' does not make for good breeding."

(Frequent births are less desirable than painstaking child rearing) (Owomoyela 2005, 270)

Obinrin tó jí ní kùtùkùtù tó ní Ọlọrun ni yó mọ iye ọmo òun, ó gbégbá irégbè "A woman who at the dawn of her life vows that only God will know how many children

She will bear has placed a load of trouble on her own head." (Children are not an unmixed blessing for women) (ibid, 282)

Omọ bẹerẹ, òșì bẹere

"A multitude of children, a multitude of misery" (ibid.)

The difference between the two dimensions of indigenous wisdom over the significance of procreation and of children becomes more complicated given the complex postcolonial realities the ethnic nationalities in Nigeria, including the Yorùbá, have to confront and engage with. Consider the implications of the indices of underdevelopment on the procreative proclivities of rural and urban Yorùbá in Nigeria.

The demographic anxiety attached to these considerations of procreative energies, as well as its social, cultural, and ontological significance, is not

5 See chapter six of Mbiti's book on God and nature to fully appreciate this existential mutual symbiosis which constitute the plight of African peoples and cultures. 
limited to the analysis of rural Yorùbá communities. Urban Yorùbá families are either under the spell of traditional beliefs or the "mandate" of modern religions. For instance, a Yorùbá Christian would likely hold firm to the injunction in Genesis to be "fruitful and multiply." One would be surprised at the number of "enlightened" Christians who refuse contraceptives as a mortal "sin" against God's injunction. On the other hand, the Yorùbá Muslim also has the permission of Islam to have up to four wives, with all the possible implications that has for careless procreation. The matter is further complicated if the modern Yorùbá is a believer in polygyny. Some comfort comes from some educated Yorùbá elites who have allowed rational choice to triumph over cultural imperatives. Our demographic angst gives way to grave national concern when it dawns on us that most urban Nigerians are part of larger cultural collectives that, as Mbiti noted earlier, are defined by the premium placed on family and its procreative capacities. Just as we noted earlier, the Yorùbá constitute a mere instance of a larger problem.

\section{Policy Makeover}

A specific dimension of Nigeria's development impasse is that there is little or no serious policy interference by government on issues of marriage or procreation. Nigeria's first population policy came into existence in 1988. That inaugural policy - the National Policy on Population for Development, Unity, Progress and Self-reliance-was reviewed, revised, and updated fifteen years later in 2004 with the National Policy on Population for Sustainable Development. In the foreword to the new document, the erstwhile president, Chief Olusegun Obasanjo, provided a justification for the revised policy:

Fifteen years after the enunciation of the 1988 Policy, the exigencies of emerging new activities and issues (the 1991 National Population Census, 1994 International Conference on Population and Development, the 1999 HIV/AIDS Summit in Abuja, poverty and food insecurity and the population-environment-development nexus issues) make a revision of the $\mathrm{Na}$ tional Population Policy necessary (Federal Republic of Nigeria 2004, i).

The 2004 Policy is realistic enough in its recognition of "certain cultural practices over time [that] have tended to contribute to growth of population of different areas of the country in ways militating against the interest of national development in contemporary times (ibid, ix).

With its recognition of the relationship between disproportionate population growth and the Gross Domestic Product (GDP) per capita, labor force, employment, housing, urbanization, nutrition, health, education, food 
security, energy resources, the public services, etc., the specific targets of the policy include:

Achieving a reduction of the National population growth rate to 2 percent or lower by the year 2015; a reduction in the total fertility rate of at least 0.6 children every five years; increase the modern contraceptive prevalence rate by at least 2 percentage point per year; reduce infant mortality rate to 35 per 1,000 live births by 2015; reduce child mortality rate to 45 per 1,000 live births by 2015; reduce maternal mortality to 125 per 100,000 live births by 2010 and 75 by 2015; achieve a 25 percent reduction in HIV adult prevalence (ibid, 23).

All of these are good and noble indeed. However, what has happened since 2004 when this policy was promulgated into law? Michael and Odeyemi outline the achievements of the 2004 Policy to include general awareness about birth control, accessibility to modern contraceptives, decrease in infant mortality rate, improvement in maternal health, and an increased awareness about HIV/AIDS and how to prevent it (2017, 107-108).

It has been fourteen years now since the 2004 Policy was reviewed, and we can begin to wonder what might have happened to the outlined achievements of the federal government, especially in the light of new population worries. How do we continue to interact with the stated targets of the 2004 Policy close to one and a half decades after it came into existence? What has happened to the fertility rate in Nigeria? Has Nigeria achieved sustainable universal education that could significantly impact our galloping population growth? The major issue, as I see it, is the lack of significant policy attention to the implementation of population policy. So far on procreation, it is all about self-regulation. The carelessness in procreation is still a major feature of population growth in Nigeria. Population is growing fast and expanding and human sustainable resources are fast dwindling. With the perennial scourge of poor governance and the paucity of good leadership, both fiscal and structural deficiencies have compounded Nigeria's underdevelopment. The barometer of poverty is now very high with the near total disappearance of the middle class. There is a perceptible resignation among Nigerians who are convinced that the government really does not care about their welfare. While Nigeria may not really be a failed state, there is no doubt that things are very bad. When a state, fifty-eight years after its independence, cannot feed its people or provide any measure of hope then the feeling of despondency is inevitable. And the population keeps up its geometric explosion! The present call in Nigeria for restructuring and return to true federalism with autonomous regions guided by their constitution is a bold attestation to the present state of 
directionlessness, hopelessness, and acute apathy. Nigeria, like many other African countries, is not guided by any defined ideology and therefore lacks any strategic operational plans or goals.

However, demographic considerations about population growth in Nigeria deserve some measure of urgency because these considerations are directly and ultimately tied to the very core of development. Population matters foreground delicate issues like food security, unemployment, rural-urban disarticulation, and even terrorism and insurgency. There is therefore the urgent need for some radical policy initiatives that arrest this drift into disintegration. Nigeria is presently fortunate because the malady is still slowly growing on her. China was not so lucky, nor was India. Even when the latter had an answer with its massive food production program, there still are obvious feelings of anger and discomfort and hence the daily shouts of fairness and equity. Uprisings have continued by iconoclastic movements that are ever ready to wage war, particularly on the obnoxious caste system that discriminates and impoverishes a huge segment of the people. China was much bolder with its response when it categorically introduced a one-child-per-couple policy to check the massive threat of overpopulation.

I wish first to propose some government policy of intervention to moderate and regulate on marriage. Save the registration by intended couples and the collection of statutory fees which often never gets to government treasury, marriage ought not to be made open to all. Marriage ought not, with the benefit of existential hindsight, be an all-comers game that is regulated by social expectations, religious injunctions, and cultural imperatives. Couples who clearly have no visible means of sustaining themselves-not to even talk of supporting a third party-have no business getting married and raising a family. Without instituting coercive measures, government may request intending partners to fill out appropriate forms to enable it determine their economic status and level of preparedness after which the excited young man and the dreaming young lady are properly advised and put on schedule. Without government giving the green light they may not marry. Certainly no inalienable rights have been violated since they could without any hindrance or interference still continue with their sexual activities strictly for pleasure.

It is also imperative for government to collaborate with non-governmental organizations that are involved with birth control efforts such as Planned Parenthood. Health institutions in collaboration should champion the initiative. They should set up counseling outposts to educate the young on marriage: what it is, what it entails, the place and significance of procreation, and how it impacts the prospect of a flourishing life and population. Everyone desires a good life. When, however, individuals are confronted with what might 
make their desire an impossibility as a result of obvious acts of carelessness and negligence, they might do a re-think.

Universities and other institutions of higher learning should also be tasked with coming up with functional curriculum in their general studies programs, particularly on civic responsibility, setting life goals, financial management, marriage, and family planning, among others. The faculties of the Social Sciences and Education should collaborate especially with the Department of Guidance and Counseling to teach and run explicit workshops that would create the necessary awareness among undergraduates. They should be taught without a shade of ambiguity that issues regarding marriage and procreation are far beyond matters of religion, culture, and tradition. It rather has to do with working with facts and frank use of common sense. Taking any wrong step on their part might simply jeopardize every chance of a good life.

\section{Conclusion}

Yorùbá society, just like other many African communities, consists of an active interaction of both the sacred and the secular, with the former-and its deities and gods-seriously influencing the latter in all of its compartments and concerns. It is clear from close interrogation of the respective cultures that generally very little critical thinking or serious interrogation is employed in their existential engagements. The transcendental, with its inherent culture of fear of the unknown and pending retribution, leaves very little room for positive independent free choices. There is also of course the overpowering, or better still an overbearing, force of an uncompromising tradition that would not allow change, insisting that things be as they are from the beginning. It is against this backdrop that it becomes imperative to angle for a critical disposition in appraising every existential choice, one of which is marriage and the subject of procreation. This is significant for assessing how these considerations impact the quality of life not only of individuals who make babies and of babies that they bring to the world, but also of society as a whole. As rational beings, it is imperative always to raise and discuss most frankly the subject of social responsibility.

Of special existential import is the prospect of population, and the danger that it portends for the security of the nation. There is first and foremost an imperative need for a paradigm shift, a new mindset, and a steady reassessment of attitudes and behaviors. No society particularly now can afford to be careless, obdurate and irresponsible about how its people live and how their everyday choices affect national development. Individuals themselves cannot afford to be sheepish with their options. It is bad enough that we as humans have been forcefully conscripted into this tough, crazy, absurd existence. Our 
pathetic state should not be further compounded with careless thinking and poor existential choices. For what it is worth, even when the promise of a pie in the sky seems utterly silly, puerile, and empty, our brief time in the sun deserves some measure of good decent living. It is of course pertinent to insist unconditionally that this huge task and responsibility of salvaging humanity belongs both to the individual and the government.

\section{Works Cited}

Benater, David (2006), Better Never to have been Born: The harm of Coming to Existence (Oxford: Clarendon Press).

Federal Government of Nigeria (2004), National Policy on Population for Sustainable Development (Lagos: Federal Ministry of Health).

Mbiti, J. S. (1969), African Religions and Philosophy (London: Heinemann).

Michael, Turnwait O. and Odeyemi, Mayowa A. (2017), "Nigeria's Population Policies: Issues, Challenges and Prospects," Ibadan Journal of the Social Sciences, Vol. 15, No. 1, March: 104-115.

Olajide, Adewale (2017a), In Defence of the Unborn and the Limit of Existential Options (Ado: Ekiti State University Press).

Olajide, Wale (2017b), "Genealogy in Yoruba Existential Philosophy," OPANBATA: LASU Journal of African Studies, Vol. 5: 175-187.

Owomoyela, Oyekan (2005), Yoruba Proverbs (Lincoln and London: University of Nebraska Press).

Pinker, Steven (2002), The Blank Slate: The Modern Denial of Human Nature (London: Penguin).

Swaab, Dick (2014), We are our Brains: From the Womb to Alzheimer's (London: Penguin).

Venter Craig J. (2007), A Life Decoded: My Genome, My Life (London: Penguin). 